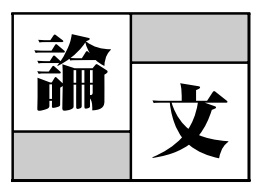

\title{
プラスチックフィルムの熱接合部に及ぼすヒーター形状の影響
}

\author{
橋 本 靜 生 ${ }^{* 1} \cdot$ 橋 本 由 美*1 $\cdot$ 山田和 志*2 宮 田 剣 ${ }^{* 3} \cdot$ 漆 山 智 之䒨
}

\section{Effect of Heater Form on Heat-sealed Parts of Plastic Film}

\author{
Hashimoto, Yasuo*1/Hashimoto, Yumi*1/Yamada, Kazushi*2/Miyata, Ken*3/Urushiyama, Satoshi*4
}

Plastic bags are used for containing and transporting goods such as foods, produce, powders, ice, magazines, comic books, chemicals and waste. Most plastic bags are heat sealed together. However, sometimes, accident occur due to poor heat sealing for complicated parts such as gusset bags. It is very important to investigate heat sealing technique for complicated bags. In this research, we demonstrate the good heat sealing properties for gusset bags by using the braid heater with a small diameter wire of nickel chrome, and the braid was made by applying the braid technique which is a Japanese traditional handicraft. As a result, the surface of braid heater has no trace after heat sealing, and the mechanical properties indicated the high peel strength as compared to common metal heater. In addition, the braid heater makes it possible to perform the heat sealing at lower temperature as compared to common metal heater, because of the high adhesion between the heater surface and the surface of gusset bags. Therefore, it was found that the heat sealing properties were improved by using the braid heater for the complicated plastic packages such as gusset bags.

Keywords : heat sealing, braid, heater, peel test

\section{1. 緒言}

我々が日常用いているプラスチックフィルムの袋は, 熱 接合によって作られることが多い.また, それらプラスチッ クフィルムの熱接合部における接着強度や接合特性は内容 物を保持する上で非常に重要で有り，例えば， OPP/CPP

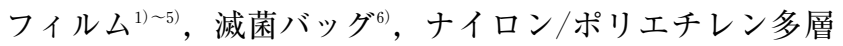
フィル ${ }^{7)}$, HDPE フィルム ${ }^{8)}$, PLA フィル ${ }^{97}$ 等の接合特 性について詳細に検討されてきた.

*1 富士インパルス秼)

FUJIIMPULSE CO., LTD

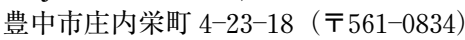

4-23-18, Shonai Sakaemachi, Toyonaka, Osaka, 561-0834, Japan Yasuo.hashimoto@fujiimpulse.co.jp

*2 京都工芸瀻維大学

Kyoto Institute of Technology

京都市左京区松ヶ崎橋上町（ $\mathrm{T} 606-8585 ）$

Matsugasakihashikamicho, sakyou-ku, Kyoto 606-8585, Japan

*3 山形大学

Yamagata University

米沢市城南 4-3-16（干 992-8510）

4-3-16, Jonan, Yonezawa, Yamagata 992-8510, Japan

*4 (株丸忠

MARUCHU CO., LTD

京都市上京区蛭子町 $644 （ \bar{T} 602-8484 ）$

644 Ebisu-cho, Kamigyou-ku, Kyoto, 602-8484, Japan 2013.3. 4 受理
一方, 近年プラスチック袋の厚みの増加や材質の多様化 に伴って, 従来のヒーターでは接合しにくい場合も生じて きている.たとえば，ガゼット袋（マチ付き袋）の場合， 接合する部分の厚みが「2 枚重ね部分」と「4 枚重ね部分」 では「倍」異なり，接合部分に段差ができるが，フィルム が厚くなることにより，段差部の接合性がより難しくなる 傾向にある. また，リチウムイオン電池などの製造におい ては，フィルムに金属タブや，リード線などを挟んで熱接 合する必要があり，タブを挟んだ部分と挟まない部分の間 に大きな段差を生じる，従来のリボンヒーター（金属薄板 のヒーター) では, 段差が大きい熱接合の場合は, 繰り返 し接合を行うにつれ，ヒーターが変形し，接合品質の低下 や接合不良を発生する。

そこで本研究では, 日本伝統の工芸品である「組紐」の 技術を用いニッケルクロム $(\mathrm{NiCr})$ の細線を「組んで」柔 軟性の高いヒーターを作製し, 段差のあるフィルムの熱接 合についてその有用性の検討を行った.

組紐と類似するものに, 編物, 織物などもあるが, 編物 はループの連続で構成されており, 織物は経糸と緯糸で織 られている. それに対し, 組紐は基本的に経糸のみで組ま れているため, 紐のどの位置においても糸の数が同じであ り，金属糸を利用した場合抵抗值が均一になることから組 紐を選んだ。 


\section{2. 試験}

\section{1 接合装置と接合条件}

接合試験に用いたヒーターは，従来使用されている接合 幅 $10 \mathrm{~mm}$ 厚さ $0.1 \mathrm{~mm}$ のニッケルクロム $(\mathrm{NiCr})$ 製「リ ボンヒーター」と, 幅 $10 \mathrm{~mm}$ の組紐ヒーターを比較検討 した．なお，組紐ヒーターは，京都西陣にある組紐製造会 社（株式会社丸忠）に依頼し，伝統的な組紐作成技術で,

$\mathrm{NiCr}$ の糸を組んで作製した。

ガゼット袋の熱接合には, 温度センサーを内蔵し, クロー ズドループで温度制御の可能な，インパルス式熱接合装置 （富士インパルス社製）を用いた。

接合条件は，ガゼット袋の熱接合に関しては，接合温度 $110 \sim 160^{\circ} \mathrm{C}$, 接合温度保持時間をこの装置の最小である $0.1 \mathrm{~s}$ 保持し, $70^{\circ} \mathrm{C}$ まで冷却した. 接合圧力は $0.4 \mathrm{MPa}$ と した.

圧力測定フィルムを用いた圧力分布試験に関しては，加 熱は行わずに，加圧作業のみを行った．接合圧力は 0.2 1.0 MPa とした.

タブを挟んだフィルムの熱接合には，熱接合装置 FT130 (富士インパルス社製) を用い，接合条件は，加熱時 間 $1.0 \mathrm{~s}$ ，冷却時間 $2.0 \mathrm{~s}$ ，運転間隔 $5.0 \mathrm{~s}$ とした.

図 1 に示すように, 本研究で用いた熱接合方法は, 上下 両面加熱であり, 本稿における「接合温度」とは, ヒーター に接した面の温度と定義する.

\section{2 ガゼット袋の熱接合}

試験に用いたフィルムは, 二軸延伸ポリエステルフィル ム, アルミ箔, 低密度ポリエチレンフィルム（以後 PET/ $\mathrm{AL} / \mathrm{LDPE}$ と記載する）で構成された厚さ $109 \mu \mathrm{m}$ のラミ ネートフィルム製ガゼット袋（構成フィルムの厚さは, PET : $12 \mu \mathrm{m}$, AL : $7 \mu \mathrm{m}$, LDPE : $90 \mu \mathrm{m}$ ) を用いた.

\section{2 .1 はく離試験}

はく離試験(10) には，フィルムを図 2 に示すように熱接 合したのち，2 枚重ね部と，4枚重ね部から幅 $15 \mathrm{~mm}$ ，長 さ $60 \mathrm{~mm}$ の試験片を切り出し, 図 3 に示すように, 熱接 合部を中心に $180^{\circ}$ 開き, つかみ具間距離 $50 \mathrm{~mm}$, 試験速 度 $300 \mathrm{~mm} / \mathrm{min}$ にて引張試験を行った. 引張試験は, イ ンストロン型万能試験機（3366 型，インストロン社製）を 用いた。

\subsection{2 示差走査熱量測定 (DSC)}

2 枚重ね部と 4 枚重ね部の接合部の DSC 測定を行った.

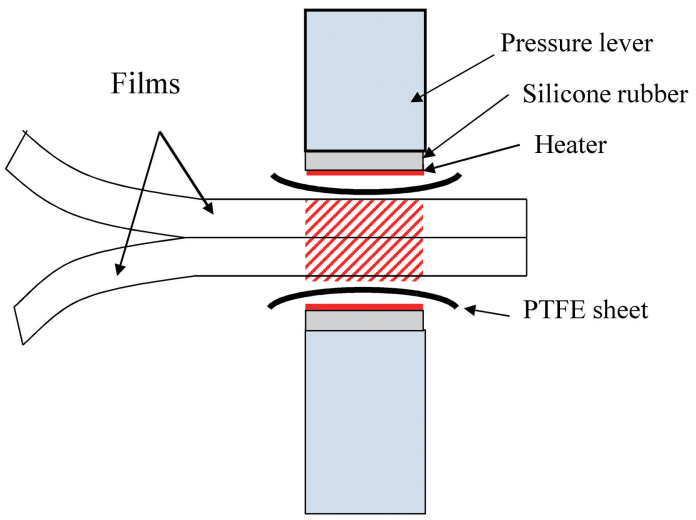

Fig. 1 Schematic diagram of heat sealing
測定には DSC 8500（PerkinElmer 社製）を用いた。試料 は, 約 $3 \mathrm{mg}$ のフィルムを精密電子天秤 (XS 105, メト ラー・トレド社製) にて精密に質量測定し, アルミニウム パンにクリンプした。測定は, 窒素雲囲気下 $(20 \mathrm{ml} / \mathrm{min})$ にて, $25 \sim 250^{\circ} \mathrm{C}$ の間を, $20^{\circ} \mathrm{C} / \mathrm{min}$ の昇温速度下で行った.

\subsection{3 圧力測定フィルムを用いた圧力分布試験}

ガゼット袋と圧力測定フィルムを重ねて，シール試験装 置で加圧を行った. 圧力測定フィルムは, プレスケール (極 超低圧用，ツーシートタイプ，富士フイルム社製）を用い た. 受けた圧力の大きさに比例して赤く発色するため，ガ ゼット袋の段差の発色してない部分の長さを測定すること ができる.

\section{3 タブを挟んだフィルムの熱接合}

試験に用いたフィルムは，PET/AL/LDPEで構成され た厚さ $79 \mu \mathrm{m}(\mathrm{PET}: 12 \mu \mathrm{m}, \mathrm{AL}: 7 \mu \mathrm{m}$, LDPE : $60 \mu \mathrm{m})$ のラミネート袋（規格袋 IA-28，富士インパルス社製）を 用い，図 4 に示すように，厚さ $0.5 \mathrm{~mm}$ のアルミ板をタブ として挟んだ. 10 回のシール作業を行い, ヒーターの外 観の比較を行った.

さらに，組紐ヒーターについては耐久試験を行い，接合 10 回後のリボンヒーターと, 接合 100 万回後の組紐ヒー ターの，接合後のフィルム外観を比較した。

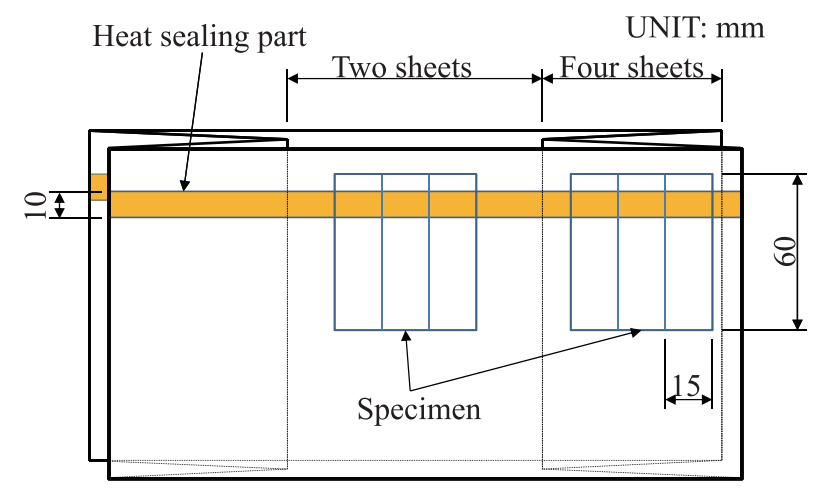

Fig. 2 Schematic illustration of heat sealing part of gusset bag
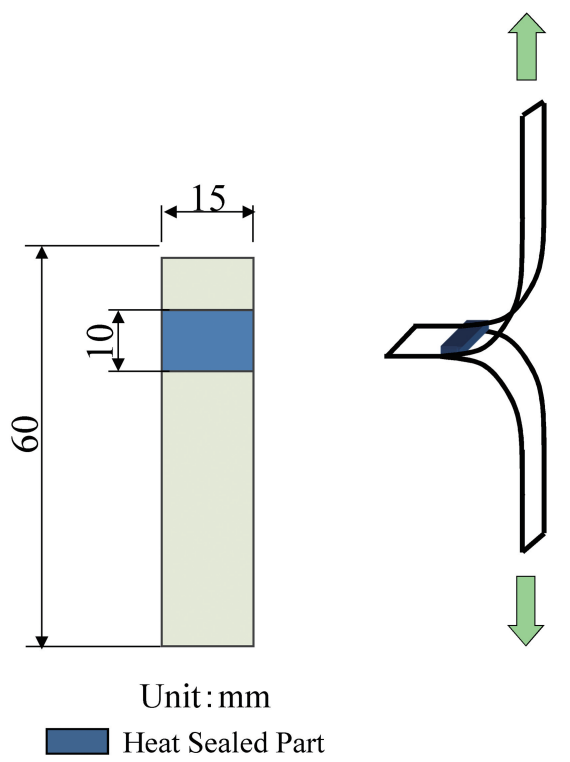

Fig. 3 Schematic illustration of specimens for peel test 


\section{3. 実験結果と考察}

\section{1 ガゼット袋の熱接合}

\section{1 .1 はく離試験}

2 枚重ね部は厚みが薄いため, 組紐ヒーター, リボンヒー ター共に, 接合温度 $110^{\circ} \mathrm{C}$ から $75 \mathrm{~N} / 15 \mathrm{~mm}$ 以上のはく離 強度が得られていたが，4枚重ね部については, 差が出た ため, 結果を図 5 に示す. 両ヒーター共に $115^{\circ} \mathrm{C} よ り$ 接合 が始まっており, $135^{\circ} \mathrm{C}$ ではく離強度は定常状態になって

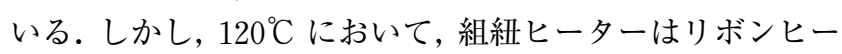
ターに比べ，はく離強度が $157 \% ， 125^{\circ} \mathrm{C} て ゙ は 130 \%$, 強 くなる傾向がみられた.

図 6 に試験後破断形態の写真と分類 ${ }^{4}$ を示す. 各試料 3 回ずつはく離試験を行った結果を A, B, C, D の破壊形 態により表している。試験片には, 次の 4 種類の破壊形態 がみられた。
$\mathrm{A} ：$ 完全はく離
$\mathrm{B}:$ 一部接合型
$\mathrm{C}$ : 接合 $(\mathrm{AL}-\mathrm{PE}$ 間はく離)
$\mathrm{D}$ ：接合 $(\mathrm{PE}-\mathrm{PE}$ 間はく離 $)$

接合温度 $110^{\circ} \mathrm{C}$ においては, 組紐ヒーター, リボンヒーター 共に接合できていなかった。接合温度 $115^{\circ} \mathrm{C}$ においては, 組紐ヒーター, リボンヒーター共に A であった. 接合温 度 $120^{\circ} \mathrm{C}$ においては，組紐ヒーターはBであったが，リ ボンヒーターは A であった。接合温度 $125^{\circ} \mathrm{C}$ においては, 組紐ヒーターは C であったが, リボンヒーターは B であっ た. 接合温度 $135^{\circ} \mathrm{C}$ においては, 組紐ヒーター, リボンヒー

\section{UNIT: mm}

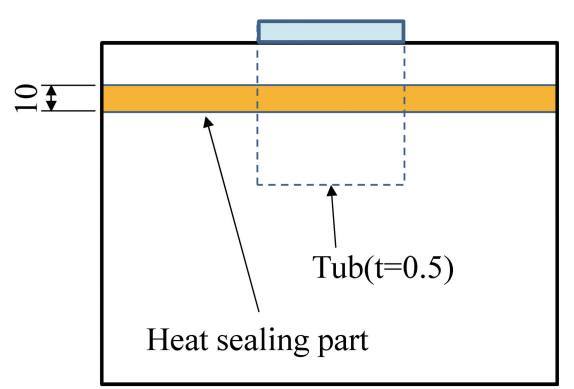

Fig. 4 Schematic illustration of heat sealing part of tub and film

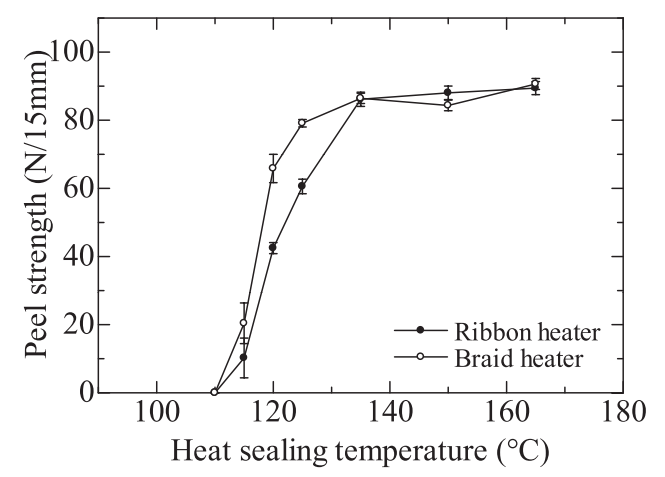

Fig. 5 Peel strength of gusset bags at 4-sheet parts for various heat sealing temperature
ター共にCであった．接合温度 $150^{\circ} \mathrm{C}$ 以上においては， 組紐ヒーター，リボンヒーター共にDであった。

\section{1 .2 示差走査熱量測定 (DSC)}

図 7 に 4 枚重ね部の DSC 結果より, 接合温度と融解熱 の関係を示す. PET フィルムの融解熱は, 組紐ヒーター, リボンヒーター共に同等であった。これはPET の融点が 約 $270^{\circ} \mathrm{C}$ であり, 本熱接合温度である $110^{\circ} \mathrm{C} \sim 140^{\circ} \mathrm{C}$ の温 度範囲では結晶化が促進されなかったためであると考えら れる。一方, $\mathrm{PE}$ フィルムでは融点が $110^{\circ} \mathrm{C} \sim 130^{\circ} \mathrm{C}$ 程度 であり，熱接合による結晶化が期待される。またグラフか らわかるように, 組紐ヒーターの融解熱がリボンヒーター よりも僅かに高い值を示した。この結晶化度の違いは, 組 紐ヒーターがリボンヒーターと比較して柔軟性があり, 試 験フィルム表面により密着可能であることから, 熱接合時 における熱伝導率が高くなり, 結果として結晶化度が高く なったと考えられる。

\section{1 .3 圧力測定フィルムを用いた圧力分布試験}

図 8 に加圧後の圧力測定フィルムの写真を示す. 組紐 ヒーターとリボンヒーターで，それぞれ $0.2 〜 1.0 \mathrm{MPa}$ ま で加圧した。中央部分は 2 枚重ね部分で, 両端の 4 枚重ね 部分に比べて，発色が薄く，圧力が低いことがわかる．段 差部分は白く抜けており, 圧力がほとんど掛っていないこ とを示す. 全ての圧力において, 同圧力では, リボンヒー ターに比べ, 組紐ヒーターの方が, 発色が濃かった. 特に $0.2 \mathrm{MPa}$ の 2 枚重ね部分において, リボンヒーターでは ほとんど発色していないのに対し, 組紐ヒーターでは発色
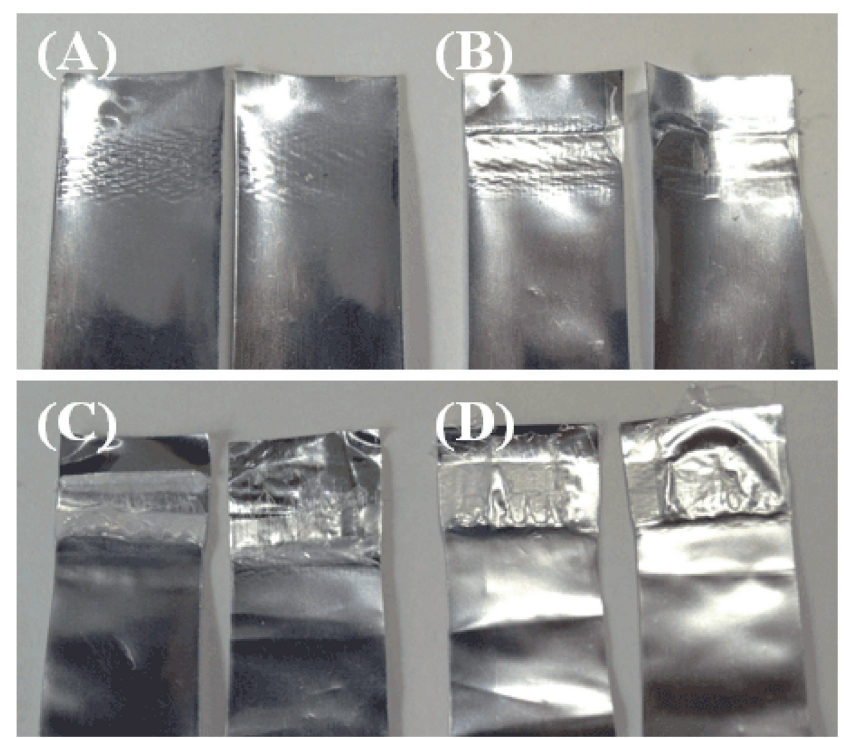

\begin{tabular}{|c|c|c|c|c|c|c|}
\hline $\left.\begin{array}{c}\text { Heat seal } \\
\text { Temperature ( }\end{array}{ }^{\circ} \mathrm{C}\right)$ & \multicolumn{3}{|c|}{ Braid heater } & \multicolumn{3}{c|}{ Ribbon heater } \\
\hline 110 & & & & & & \\
\hline 115 & A & A & A & A & A & A \\
\hline 120 & B & B & B & A & A & A \\
\hline 125 & C & C & C & B & B & B \\
\hline 135 & C & C & C & C & C & C \\
\hline 150 & D & D & D & D & D & D \\
\hline 165 & D & D & D & D & D & D \\
\hline
\end{tabular}

Fig. 6 The classification of peeling surface of specimen after peel test 
が見られ，また，組紐ヒーターは，リボンヒーターに比較 して，組んだ「目」の痕が見られた。

図 9 に, 図 8 で示した画像の, 段差の白く抜けている部 分の幅を左右 2 ヶ所測定し, 横軸に圧力, 縦軸に幅をとり, プロットしたものを示す.リボンヒーターに比べ, 組紐ヒー ターは, 段差の白く抜けている部分の幅が約 $30 \%$ 短く,

よりガゼット袋の段差に，ヒーターが密着していることが わかる。

図 10 に, 図 8 で示した画像の，2枚重ね部と 4 枚重ね 部の断面の色の変化を数值化（スペクトル化）したものを 示す. RGB 值で表しているため, 縦軸が 0 〜 255 まで数值 化されており，0に近いほど黒，255に近いほど白である ことを示す. 感圧紙で圧力の強い部分は赤色が強く発色し ているため, RGB 分解スペクトルでも, 赤線はほほ 255 に近い值を保持していることがわかる．また，圧力を感知 していない部分は白色であるので, RGB 值は 255 に近く なる。従って, 測定結果において, リボンヒーターで接合 した際には，(d)や(e)の場合には, 圧力がゼロに近いの に対して, 組紐ヒーターを用いた場合には，2枚重ね部に おいても圧力が伝わっていることがわかる.

以上の実験結果より，ヒーターを組紐にしたことで，柔

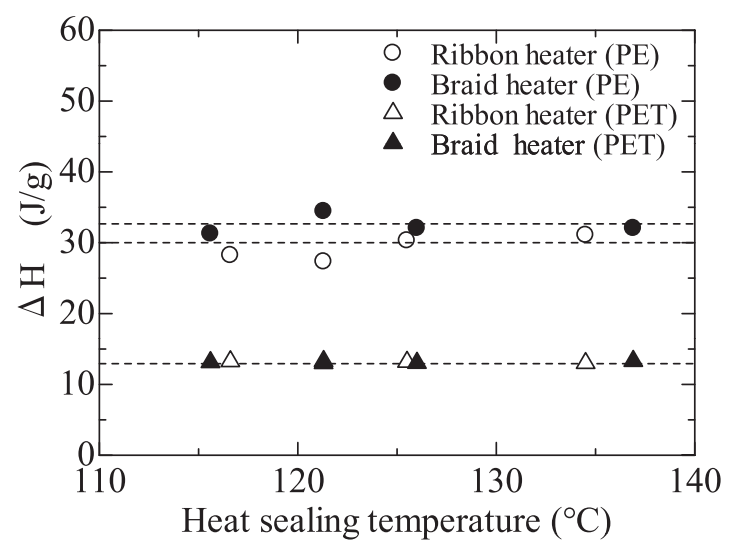

Fig. 7 Heat of fusion at heat sealed parts for various heat sealing temperature

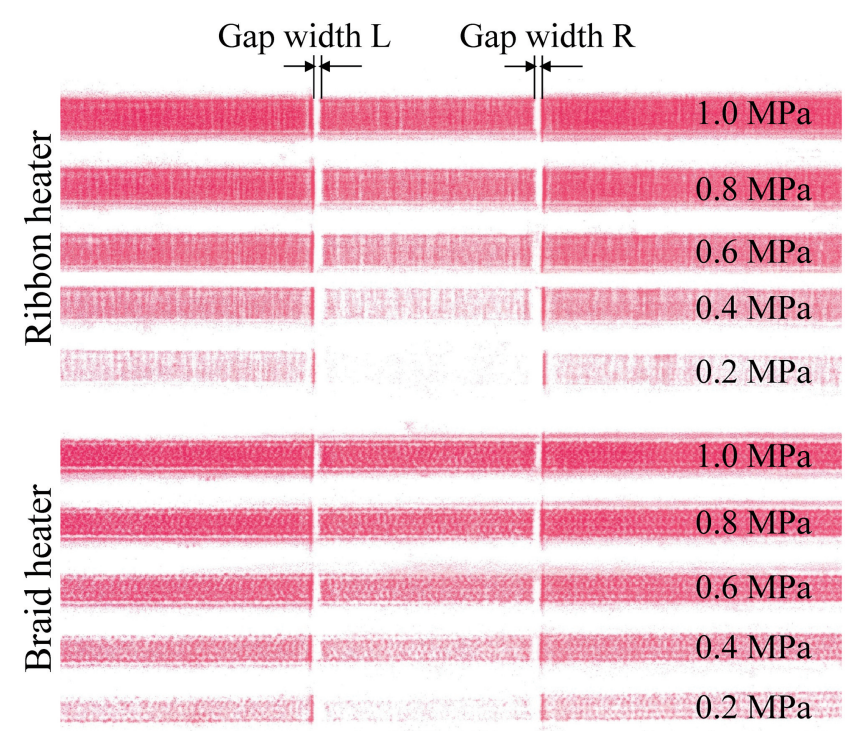

Fig. 8 Pressure distribution images for each specimens
軟性が増していることがわかる，また，低い接合温度から 熱接合が可能であることについては, 組紐ヒーターが, 細 線で組んであるため, 組目があり, 表面が平たんではなく, 凹凸部分が存在する。 そのため凸部に圧力が集中して，低 い加圧力時においても, リボンヒーターに比べて凸部に熱 が集中し, その部分が起点となって, フィルムが溶融しや すくなっているのではないかと考えられる.

\section{2 タブを挟んだフィルムの熱接合}

図 11(a)にリボンヒーターの接合前と接合後の外観写真 を示す．接合前のヒーター表面は歪みの無い鏡面状態であ るが，接合後では，縦方向に多くの圧痕が見られる．この 圧痕は接合回数が増えるにつれ多くなり，接合時にフィル ム側に転写されるため，接合部品質が悪化し，最後には接 合不良の原因となる。図 11 (b)に組紐ヒーターの接合前と 接合後の外観写真を示す．リボンヒーターに比べ，全く圧 痕が見られなかった。

図 12 に耐久試験後のヒーターを用いた接合部の外観写 真を示す.リボンヒーターにおいては, 接合 10 回後です でにフィルムにヒーターの圧痕が転写されてしまっている が, 組紐ヒーターにおいては, 接合 100 万回後でも圧痕の 転写は見られなかった。

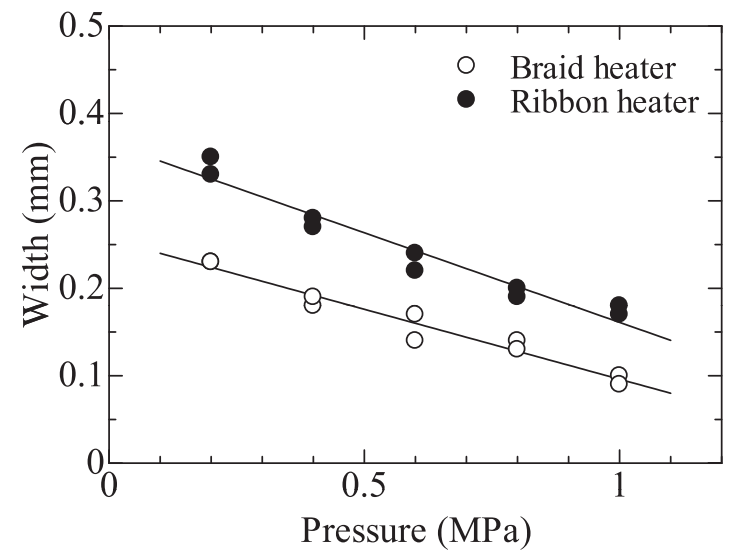

Fig.9 Plots of gap width for various heat sealing pressure
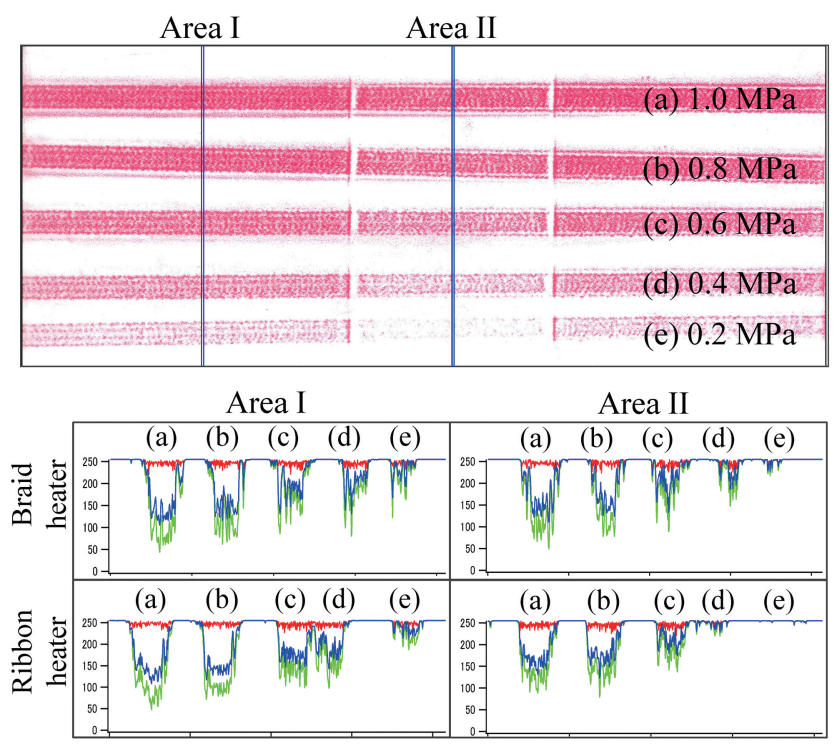

Fig. 10 Analysis of pressure distribution images of heat sealing pressure for gusset bags 
これらのことより, 組紐ヒーターは柔軟性が高く, 接合 時には，段差を吸収し，接合後には，元の形状に戻ってい ることがわかる。

\section{4. 結言}

本稿では, 組紐技術を用いた金属ヒーターの, プラスチッ クフィルム接合装置への適用について検討した.

ガゼット袋の熱接合の結果から，はく離試験において， 組紐ヒーターで熱接合を行うとリボンヒーターよりも低い 温度で, はく離強度が高くなり, 漏れにくいことがわかっ た. DSCにおいて, 組紐ヒーターはリボンヒーターに比 ベ，PEフィルムの結晶化度が高く保たれていることがわ かった. 圧力分布試験において, 組紐ヒーターはリボンヒー ターに比べ，よりガゼット袋の段差にヒーターが密着して いることと，2枚重ね部においても圧力が伝わっているこ とがわかった。これらの結果は, 組紐ヒーターの表面に, 凹凸部分が存在するため，低い加圧力時においても，凸部 の圧力が高くなり，フィルムが溶融しやすくなるからでは ないかと考えられた。

タブを挟んだフィルムの熱接合の結果から, 組紐ヒー ターは, 従来用いられていたリボンヒーターに比べ, ヒー ターへの圧痕も見られず，耐久性にも優れていた。

これらのことより, 組紐ヒーターはリボンヒーターに比 べて, 柔軟性が高く, 接合時には, 段差を吸収し, 接合後 には，元の形状に帍っているためと考えられた.

\section{参 考 文 献}

1 ) Tsujii, T., Ishiaku, U. S., Mizoguchi, M. and Hamada, H. : Journal of Applied Polymer Science, 97(3), 753 (2005)

2 ) Tsujii, T., Hashimoto, Y., Ishiaku, U. S., Mizoguchi, M., Leong, Y. W. and Hamada, H. : Journal of Applied Polymer Science, 99 (2), 513(2006)

3 ) Hashimoto, Y., Ishiaku, U. S. and Hamada, H. : Polymer Engineering \& Science, 46(2), 205 (2005)

4 ）橋本由美, 橋本靜生, 辻井哲也, 森本光彦, 小滝雅也, 㴿田泰以：成形加工，19(4)，236(2007)

5 ) 橋本由美, 橋本靜生, 山田和志, Yew Wei LEONG, 㴿田泰以：日本包装学会誌，20(4)，273(2011)

6 ) 橋本由美, 橋本靜生, 辻井哲也, Yew Wei LEONG, 山田和志, 㴿田泰以：日本包装学会誌，18(4), 251 (2009) (a) Ribbon heater

Before

After

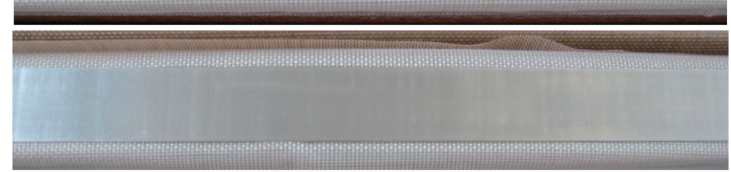

(b) Braid heater

Before

After

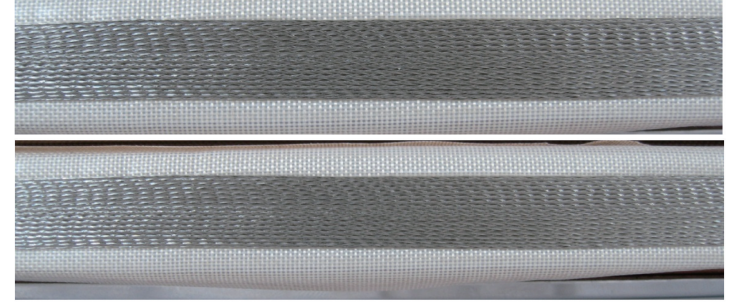

Fig. 11 Photographs of heater part before and after heat sealing

(a)

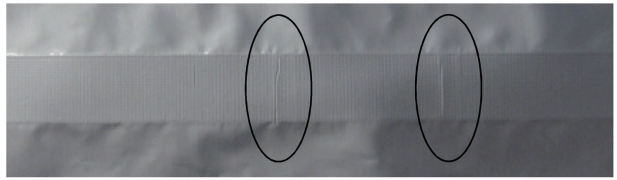

(b)

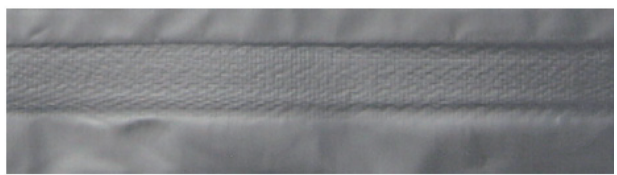

Fig. 12 Photographs of heater surface after heat sealing, (a) 10 times for ribbon heater, (b) 1, 000, 000 times for braid heater

7 ）小西礼一, 山田和志, 橋本靜生, 辻井哲也, Yew Wei LEONG，宮田剣，㴿田泰以：日本包装学会誌，19 (6) , 461(2010)

8 ）橋本靜生, 橋本由美, 山田和志, 宮田剣：成形加工, 23 (11)， 691(2011)

9 ）橋本由美, 橋本靜生, 山田和志, 演田泰以：日本包装 学会誌, 21(2), 115(2012)

10) Hashimoto, Y., Hashimoto, Y., Tsujii, T., Yamada, K., Leong, Y. W. and Hamada, H. : Journal of Packaging Science \& Technology, 17 (4), 265 (2008) 